\title{
Rethinking Civil-Military Relations in a Pakistan: Some Lessons from Turkey
}

\section{Zhao Shurong and Saif Ur Rahman}

School of Political Science and Public Administration, University of Electronic Science and Technology of China, PR China

*Corresponding author: Zhao Shurong, School of Political Science and Public Administration, University of Electronic Science and Technology of China, PR China Tel: +862861831756; E-mail: shurz2015@163.com

Rec date: Jul 03, 2017; Acc date: Jul 10, 2017; Pub date: Jul 20, 2017

Copyright: ( 2017 Shurong Z, et al. This is an open-access article distributed under the terms of the Creative Commons Attribution License, which permits unrestricted use, distribution, and reproduction in any medium, provided the original author and source are credited.

\begin{abstract}
Pakistan and Turkey enjoy great similarities in many aspects. Yet, the greatest similarity among them is the history of military interventions in domestic politics. The elected governments have been overthrown by the militaries in both the countries, imposing martial laws intermittently. However, since its gaining power in 2002, the government of Justice and Development Party (AKP) has taken series of steps to re-balance Turkish civil-military relations in favour of elected government, which have proved successful in thwarting coup attempts by the country's military.

Pakistan being a parliamentary democracy has no place for its military to indulge in domestic politics. However, Pakistan has remained under direct military rule for half of the country's existence. For the remaining half, a fragile democracy existed with ominous threat of military rule. In this article, an attempt has been made to identify the causes of military's intervention in domestic politics in Pakistan. Some parallels have been drawn to the transforming civil-military relations in Turkey, with a view to draw some pertinent lessons for Pakistan. This article suggests certain first and second-generation measures for democratic government in Pakistan for ensuring civilian supremacy in civil-military relations as enunciated by its constitution.
\end{abstract}

Keywords: Pakistan army; Military politics; Turkish military; Civilmilitary relations; Military intervention; Pakistani politics; Military and democracy

\section{Introduction}

The July 2016 failed coup attempt in Turkey was widely discussed in media and political circles alike in Pakistan. On the eve of the visit of Turkish president recep Tayeb Erdogan to Pakistan, the prime minister of Pakistan said during the joint press conference that Turkish people have set a great example by foiling a coup attempt recently [1]. In this article, the dynamics of Pakistan's military intervention in domestic politics have been discussed while analysing, relevant example from the countries, where the civilian supremacy in civil-military relations were achieved successfully.

Pakistan came into being in a volatile security environment as a seceding partner of British India in August 1947. The complex internal and external threats dictated the country to invest heavily in defence sector. The cold war era further modernized Pakistan Army. The military used its advancement and foreign support to occupy domestic power. After the decades of rule, Pakistan army self-assumed the guardian role and expanded its corporate interests, evolving into a praetorian military. Military directs foreign policy as well as domestic policy and exclusively controls nuclear weapons program of the country. With greater awareness and freedom of media in $21^{\text {st }}$ century, there is an increasing demand from the public to cut down Military's role to its legitimate position in the constitution.

\section{Literature Review}

Volumes of literature exists explaining the reasons of military intervention in domestic politics, however, the special aspect of Pakistani military intervention in politics has not been widely debated in Pakistan, partly because of the reason of military enjoying a status of "sacred cow" at home and any objective criticism directed towards military establishment is regarded synonyms with un-patriotism and may bringing reprisals through formal as well as informal means. Samuel P Hungten proposed the theory of separation for keeping the military under the supremacy of civil control on the pattern of Western democracies. Hungten's formulations were based on post world war-II civil-military relations of America. Rebbeca Schiff has given the theory of concordance for civil-military relation. Military interventions in domestic politics occur only where there is discordance between the three partners. The author further elaborates the three partners of concordance as the military, citizenry and political elite to agree over four indicators such as military recruitment, political decision making and military style [2]. Another view of military's intervention in state politics is described by Nordlinger with a tripartite classification based on the powers exercised by intervener and the type of goals pursued [3]. The lowest level of interventionists is the "Praetorian Moderates" who act as pressure groups mostly and avoid indulging in direct government. They return power to the civilian rule after "displacement coups". The second category is of "Praetorian Guardians" who share the values of moderates but willing to take over the power usually for two to four years and preserve the system which serves the military interests. The last category is of "Pretorian Rulers" who deeply involve in governance and extent their rule. They embark on an ambitious economic and political agenda and when they handover power, they maintain the status of praetorian moderates, keeping watchful eye on the civilian government. In an another discourse on democratizing 
civil-military relations in Eastern European countries, Andrew Cottey suggests in his article "second generation problematics" that after the fall of communism, the East European states have formalized first generation reforms, while there is need for a second generation reforms for civilian governance of defence and security sector [4]. The first generation of reforms include the institutional and legal reforms to bring military under the control of civil executives, while the secondgeneration reforms are the practical manifestation by state capacity building. The first-generation reforms de-legitimize the military intervention in politics and state affairs while the second-generation measures ensure its implementation.

\section{Causes of military's intervention in domestic politics in Pakistan}

Pakistan is a parliamentary democracy as per the constitution adopted in 1973, therefore, a structure of civilian oversight of military matters exist. Army is among two other branches of defence forces including navy and air force which falls under the defence ministry where the secretary defence is the senior most bureaucrat to run the affairs of the ministry. The secretary defence is answerable to the defence minister who in turn is responsible to the cabinet and prime minister on the defence matters. But, the situation on ground is quite contrary to the theoretical framework enunciated in the constitution. The military has been making coups up to four times in the past since 1958 and directly ruled the country for almost 35 years out of the country's seventy years of existence. For remaining half, it has played the role of king maker from behind the scenes. It has nurtured loyal politicians, political parties and crafted electoral manipulations to get its favourable parties to the power [5]. Some of the important reasons of Pakistan turning into a garrison state are elaborated in successive paragraphs.

Pakistan army, as an institution had a leading start at the inception of the country. Pakistan received 33\% of military shares and only $17 \%$ of monitory reserves as a seceding partner of British India in the postcolonial partition arrangement in 1947 [6]. The initial war with India in 1948, the internal discord with in the provinces and mounting fears that the partitions will be undone by India, compelled the founding fathers of the newly born state to invest heavily into defence at the cost of other institutions. The founding leaders died soon after Pakistan came into existence without formulating a constitution for the new republic and without setting a clear course for the future of the country. Commander in chief of the armed forces exploited the vacuum and encroached into the power corridor by assuming the portfolio of defence minister as early as 1954 and sealing the fate of the country by imposing first Marshal Law in 1958 [7].

Abetting military rule by world powers especially USA remained another reason of military's involvement in domestic politics. In postworld war II scenario, Pakistan came into forefront of US foreign policy of containing Soviet Union. Dealing with one man in military was an easier task for US than a chaotic parliament and array of political leaders in Pakistan. Thus, the cosiness between USA and military rulers in Pakistan from General Ayyub to Pervez Musharraf were corrosive for democratization and civilian supremacy in its civilmilitary relations [8]. The prolonged rule gave military the opportunity to direct Pakistan's foreign policy single-handedly and shape the domestic politics.

The weak, inept and corrupt civilian institutions encouraged military to take all the state matters into its hands. Though, it is argued that, during the repressive military regimes, the civil, political and social institutions of the country were never allowed to be strengthened. Important state institutions like judiciary, legislature and media were coerced to legitimize military rule. Along with state institutions, the citizenry at large also did not resist to the abrogation of constitution by the military. This apparent indifference was due to low literacy rates and lack of awareness among population about the rule of law [2].

To safeguard its corporate interests, it's imperative for the military to dominate other state institutions. During the decades of rule, Pakistan Army has evolved into a praetorian military. It runs almost fifty business conglomerates ranging from the commercial banks to the plants of fertilizers, cement, sugar and many other commercial products [9]. Military is also heavily involved in the real-state business in the country. According to Dr Ayesha Sidiqa, Pakistan's military is the largest land owner within the country. Military controls $12 \%$ of the total state land [10]. It has the capacity to convert the state land from official to private use unlike other institutions which also possess state land in Pakistan. The distribution of economic gains generated from military business is skewed towards military hierarchy. The estimated worth of legally acquired assets of a Pakistani Military's general is \$2.59 million to $\$ 6.90$ million in a country like Pakistan, where two third of its population lives below poverty line (one dollar a day) and another twenty percent just above it [6].

\section{Re-balancing civil-military relations in Pakistan}

In a parliamentary democracy, defined boundaries exist for civil and military institutions, therefore, Pakistan does not require major structural reforms. However, the military tutelage which comes off due to its informal mechanisms of state control need to be revisited and a few second-generation reforms needed to re-balance civil-military relations in Pakistan.

Turkey initiated its statuary reforms in February 2002 as a result of Copenhagen criteria for the accession to European Union membership [11]. These harmonization laws proved to be a stepping stone for rebalancing the civil-military power in favour of elected government in Turkey. During the military rule, National Security Council (MGK) was set up to provide a legalized role for Turkish armed forces in governance of the country. The AKP government amended the role and composition of National Security Council (MGK) with more civil representation and making its recommendations advisory rather than priority [11]. Whereas in case of Pakistan, military had long been desirous of its institutional role in country's governance. The Pakistan Muslim League government sacked its army chief in 1998 for the letter's proposal of forming national security council on Turkish lines. However, in 2013, the same government legalized defecto military dominance over national security affairs by reconstituting Defence Committee of Cabinet (DCC) into Cabinet committee of National Security (CCNS) [8]. In DCC, the services chiefs were only invited when needed while in CCNS, they were made a permanent part of the cabinet, putting its democratic credentials in question where uniformed men were made permanent part of cabinet committee. Pakistan's parliament and its standing committee on defence need to play an active role in security policy making and scrutinizing the defence expenditures for effective civilian oversight of military matters.

Another land mark constitutional reform by AKP government in Turkey was its amendment in the contents of article 35 which gave military the authority to intervene in domestic politics whenever it considered the internal security was at risk. The provisions of state 
security courts were also repealed from the constitution, where civilians were being tried by military. AKP government also passed an amendment to 1982 constitution allowing the military officers to be tried in civil courts for offenses against constitutional order [12]. As a result, over 200 military officers and men including former army commander of land forces were arrested and investigated in 2007 for alleged conspiracy against the elected government. The Erdogan government also responded proactively to the warnings issued by military in 2007 about the suitability of its political candidates, reminding the military that it had no authority to instruct government in its affairs. Whereas, in Pakistan's case, a weak democratic government is in a permanent state of danger from military intervention. A religious cleric Tahir ul Qadri along with the cricketer turned politician Imran Khan staged a long march and sit-ins in 2014 demanding the prime minister to step down. During the protests, a stage came when the military takeover of government seemed imminent. The army chief instructed the government through public statements not to use force when the raged protestors marched on to the parliament and prime minister house [13]. The elected government in Pakistan, unlike Turkey could not have the courage to remind army chief about his constitutional position of being answerable to prime minister. Allegedly, these protests were backed by the premier intelligence agency of the country and some generals in military [14]. The government could not investigate these allegations.

The first ever transition of power between the elected governments in Pakistan's history came after the elections of 2013. The Sharif government after coming into power in 2013, initiated a trial of general retired Pervez Musharraf for his extra constitutional steps of abrogating the constitution; however, the government could not sustain military pressure and allowed him to proceed abroad to obviate the trial [15]. Historically, the generals have never been held accountable in Pakistan. The elected government in Pakistan needs to learn from the Turkish case and hold military generals accountable for breaking their oath and violating the constitution, to dissuade any future military interventions in politics. The Hamood Ur Rahman commission report on 1971 debacle needs to be made public and an inquiry of Kargil issue needs to be done which was publicly committed by prime minister Nawaz Sharif before the elections of 2013. The Sharif government gave some unusual concessions for military to encroach into civilian domain of governance under National Action Plan (NAP) for combating terrorism. The military courts were established and apex committees were formed involving corps commanders in provincial law and order issues. The elected government in Pakistan needs to strengthen state institutions rather involving military in the judicial, executive and policing matters.

In Pakistan, when military is not involved in direct rule, it interferes in domestic politics through its informal means more than the formal one. The intelligence agencies, which have acquired huge capabilities, resources and operational independence initially during the cold war era and then during the recent war on terror have often used its apparatus in domestic politics. The former director general ISI (Inter Services Agency) accepted the role of his agency in electoral manipulations by bribing politicians in 1991 elections [5]. ISI operates in the country in a state of legal vacuum [8]. It's a federal agency under Prime minster, without any federal body to monitor, regulate and control the agency. Though it is directed and influenced by army as its director general and most of the officers come from army. However, legally ISI is not under general headquarters either. A parliamentary committee under prime minister should be set up as a legal body on the lines of US congressional committee on intelligence, to monitor, control and regulate the operations of ISI. The induction of civil officers in ISI should be increased giving them opportunities for promotions to senior positions. The outlook of ISI should be made as a civilian agency headed by a retired military officer or a civilian bureaucrat for a more civilian control of defence matters. Reforming of the country's premier intelligence agency and its role in politics was agreed by the Pakistan Muslim League Nawaz (PMLN) and Pakistan People's Party (PPP) during the charter of democracy signed in 2006. An order issued by the previous PPP government placing ISI under interior ministry was retracted overnight without giving any justification [16], which reflects how fiercely military guards itself from the oversight of elected government in Pakistan.

Separation of domestic and external violence making forces is an important norm of democratic civil-military relations. In Pakistan's context, this distinction is blurred with army's monopoly over paramilitary Forces. The paramilitary forces (rangers, frontier corps and frontier constabulary) responsible for border protection and internal security come under the interior ministry and provincial governments in Pakistan. These forces are controlled by officers sent from army giving it an extra layer to indulge in domestic security matters. Federal or provincial governments have customary command over these forces and they are directed, controlled and operated by military command. In some instances, the ranger forces in the province of Sind were accused by the provincial ruling party for exceeding their mandate and making some politically motivated arrests of corruption cases. The corruption was linked with terror financing to bring the political arrests with in the mandate of Rangers [17]. It clearly reflects that the military rather than provincial government controls the paramilitary forces. The ranker officers of paramilitary forces should also be allowed to rise to senior posts. The officer corps of these paramilitary forces in Pakistan should have a broad representation from police, military and civil services and made truly responsible to provincial government for increasing civilian control of internal security matters. In India, the border security forces have their own cadre of officers and the force is headed by a police officer, whereas, in Pakistan's paramilitary forces the ranker officers are denied promotions after they achieve a certain middle rank [18].

Due to the overbearing military influence, both the elected and military governments have militarized the civilian administration in Pakistan. The civilian professionals are dismayed at the appointment of retired military officers to the senior slots of civilian administration, to which they neither have a qualification nor experience. Appointment of retired Lieutenant General as Chairman WAPDA (Water and Power Department) by Sharif government in Aug 2016 is a testimony of the fact [19]. Moreover, through the military quota in civil administration introduced by General Zia's regime, military maintains tutelary influence over civil administration [8]. With the help of this quota, military officers are inducted to civil posts in public administration, police and foreign service directly as compared to their civil counter parts who go through a rigorous competitive process. These military officers in civil services maintain close contact with their colleagues in military and intelligence agencies, and act as a tool of military influence in civil administration. The induction of military officers to civil departments to be made equally competitive to that of candidates applying from civil for maintaining transparency. Moreover, civil departments should be de-militarized to reduce the imperious military influence over civil institutions.

Turkish president Gul and prime minister Erdogan participated the supreme council (YAK) annual meeting for military promotions in 
2010. AKP government successfully influenced military promotions by blocking generals officers' promotion who were under investigation for plotting coup against government [12]. Pakistan's military enjoys complete autonomy over its internal promotions, transfers and appointments except prime minister selects next army chief from the five candidates recommended by chief of army staff. the corps commanders play a key role in influencing the decisions of army chief and military policy formulation. The elevation of law abiding, nonpolitical and professional generals to the post of corps commander is vital for military's commitment to democratic norms and the rule of law. The prime minister or a special committee of cabinet must have a vetting power to block any candidate in the last promotion board to the lieutenant general in the army for a sustainable democracy in Pakistan.

Military in Pakistan gets opportunity to intervene only when the domestic situations deteriorate and the elected governments fail to perform. Good governance is a prerequisite for a sustainable representative government. The elected government in Pakistan needs to prove through their performance that democracy is the better course for the country. The previous government of Pakistan People's Party had a deficient performance on economic front. However, it can be credited for putting Pakistan on the course of parliamentary form of democracy again by restoring the constitution to its original form and repealing the amendments carried out during the military rule. The present government has fared well in economic progress. Under Sharif government Pakistan was termed fastest growing Muslim Country and $5^{\text {th }}$ fastest economy in the World for the year 2015 [20]. The bold steps of AKP government in containing military power in Turkish politics was primarily successful because of its massive economic progress. AKP won three consecutive election since 2002, which is indicative of the national confidence on the party leadership. Pakistani elected leaders need to learn lesson from Turkish economic progress that the nation will only stand with democratic forces if the elected leaders can deliver.

Military in Pakistan guards its image jealously and uses all covert and overt measures to propagate its heroic image. Military's building of its image as saviour of the state is crucial for national psyche of hoping military to intervene when the situation deteriorates. Military in Pakistan maintains considerable number of media outlets, radio stations and coopted journalists in the media circles. In 2016, Asma Jahangir, a prominent human right activist and lawyer filed a case in Supreme Court of Pakistan asking the government to disclose the source of income, expenditures, and the regulations under which Inter services Public Relations (ISPR), the military's media wing is functioning [21]. She argued that the ISPR has a huge media cell and it is used to defame individuals. The elected government should not let the public to lose their confidence on democracy and rule of law. AKP in Turkey gained more and more popularity since its elections in 2002. It made a history in Turkish politics by increasing its share in Parliament in every coming election while remaining in power. Large part of this popularity can be attributed to articulated media campaign. As of 2009, AKP funded 19 daily newspapers, 120 magazines, 51 radio stations and 20 television channels [12].

Turkish military had been dominating foreign and domestic policy till the end of 1990s. The militaristic foreign policy of Turkey had developed problems with most of its neighbours. the cyprus issue was considered a "national cause" by military. Under AKP rule, the Turkey's external relations also witnessed a turned around. It pursued a "zero problem policy "with all the neighbours, redefined its position on
Cyprus and backed annan plan of reunification of cyprus. Internally also, AKP adopted appeasement policy towards Kurd minority. Due to economy-based foreign policy and regional integration, Turkish trade with neighbours grew six folds during the AKP rule [12]. Pakistan has also been turned into a security state due to its militaristic foreign policy. The domination of foreign policy by military has severed Pakistan's relations with three out of the four immediate neighbours. The suppression of dissent at domestic front has already costed the country heavily. The promotion of militarism has neither won the Indian held Kashmir nor did the policy of "strategic depth" towards Afghanistan brought any positive returns. It is high time for the military in Pakistan to learn from the past experiences and let the art of "diplomacy" be done by the professionals.

\section{Conclusion}

In Pakistan, the path of democracy is perilous one. However, returning of the country to democracy after every military coup indicates that the nation's faith in rule of law and representative governments has not diminished yet. The coup makers in Pakistan also displayed their allegiance towards democracy by announcing to bring "real democracy in Pakistan" speaks all about the fertility of this land for the representative form of governance. The military governments have always tried to demonize politicians and political process but they have not been able to evolve into a lifelong dictatorship. Pakistan needs to evolve into a practicing democracy with a civilian supremacy in its civil-military relations.

The military rule itself has only been a temporary relief for Pakistan's problems. Pakistan faced worst crisis in its history including its dismemberment during the military rule. The national fabric was weakened and military policies on external fronts also failed miserably. The military in Pakistan needs to learn from the past and let the elected governments to complete their tenure in office repeatedly without direct or indirect intervention in domestic politics, to evolve stable democratic institutions in the process. The country needs to follow an economic led foreign policy with civilian supremacy in civilmilitary relations for political stability, social harmony and economic prosperity in Pakistan. Though, there are minimal chances of direct military rule in Pakistan, however, Pakistani politics seems to be dominated by military through its informal means for the foreseeable future.

\section{References}

1. Reporter S (2016) People of Turkey have set an example by foiling a coup attempt-prime minister. Daily Jang, 18 November 2016, Jang Group: Rawalpindi: 18 .

2. Schiff RL (2016) Concordance theoryin Pakistan: Responseto Zulfiqar Ali. Armed Forces Soc 42: 226-234.

3. Hickman CSAJ (2013) Soldiers as saviours of the state: The cases of Turkey and Pakistan contrasted. Journal of Third World Stud 30: 39-54.

4. Cottey A (2002) Second generation problematic: Rethinking civilmilitary relations. Armed Forces Soc 29: 31-56.

5. Muneer A (2012) The political role of the ISI, in The Express Tribune March 17: Islamabad, Pakistan.

6. Haqqani H (2009) Pakistan; between mosque and military. Carneige endowment for international peace, Washington DC. USA.

7. https://en.wikipedia.org/wiki/Ayub_Khan_(general)

8. Shah A (2014) The army and democracy, military politics in Pakistan. Harward University Press Cambridge, Massachusetts, USA. 
Citation: Shurong Z and Rahman SU (2017) Rethinking Civil-Military Relations in a Pakistan: Some Lessons from Turkey. J Socialomics 6: 209. doi:10.1472/2167-0358.1000209

Page 5 of 5

9. Wasim A (2016) 50 Commercial entities are being run by armed forces. The Dawn, Pakistan. 21 July 2016.

10. Aljazeera (2008) Pakistani army's '\$20bn' business, Aljazeera, Doha, Qatar

11. Michaud Emin L (2007) The restructuring of the military high command in the seventh harmonization package and its ramifications for civilmilitary relations in Turkey. Turkish Studies 8: 25-42.

12. Bardakçi M (2013) Coup plots and the transformation of civil-military relations in Turkey under AKP Rule. Turkish Studies 14: 411-428.

13. Khan MI (2014) Pakistan protests: Nawaz Sharif cornered. bbc.com, Pakistan, 2 Sep 2014.

14. Zahra M (2014) Army chief holds off generals seeking Pakistan PM's ouster. in Reuters, 5 Sep 2014.

15. Desk S (2016) Raheel Sharif 'helped me out' in leaving Pakistan: Musharraf. Pakistan The Dawn.
16. Raza SI (2008) Govt forced to withdraw ISI decision. The Dawn, Pakistan28 July 2008.

17. Rehman ZU (2015) Crime down in Karachi, paramilitary in Pakistan shifts focus. The New York Times, Pakistan.

18. Admin. (2016) Border security forces of India. Knowledge of India 2016: 11 Sep 2016.

19. Desk S (2016) New Wapda chairman takes charge. The Dawn, Lahore, Pakistan.

20. Desk W (2015) Pakistan: The fastest growing Muslim economy. The News Web, Pakistan.

21. Iqbal N (2016) How many FM stations under ISPR: Asma asks SC. The Dawn, Pakistan. 